PIIRENIO NERVE INJURIES, HEPOIT OF A OABE. ANATOMIOAL AND EXPERINENTAI, HISEAROIES, AND ORITIOAL REVIEN OF TIIE IITERATURE,*

By W. E. Sctroozdra, 31.D.,

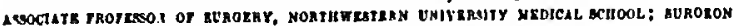
TO THE WELEY, PROTHENT, AND COOK COUNTY HOSPITALS.

พ1тH

ANATOMIOAL OUBERVATIOAB ON THE INKERVATION OF THE MAPHRAOM.

BY I., I., GREes, A.M., M.D.,

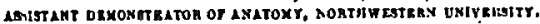

IN $\mathbf{n}$ eareful oxamination of tho literaturo on this subject, one finds that mast autlorities agreo that a division of tho plirenio nervo or any injury to lt is tatal, or ecrtaialy very daugerons. I was led to doubt tho aecuracy of this conclusion, firat, by a case of paralysis of the right lialf of the diapliraga, conpliented by a diaplingnatio hernin follow. ing an antorior poliomyelitis which I eaw In 1892 ; eccondly, by $\mathrm{Dr}$. Murphy's nitrogon gas nethod of collapsing ono lung for tuberenlosis; and thilrdly, by eases of rocovery fron surgienl puemunothomx, whleh mado ano thiok that tho worat that coulil happen in Injury to tho plureutio nerro would loo a paralysis of one-half of tho dinplurngu lenting to a partial collapso of ono lung only.

My skepticisim led one to tako liberties witlı tho nerre, so that reeently I lavo puinelied lt systematically every timo lt has lieen exposed during a tuberenlar glaud oporntion, aftor Fongor's' method, and when, furing an oporation for a tumor of tho neek, it was found impossiblo to removo it without dividing tho nervo, I did so unhesitntingly.

I am indobted to Dr. J. Fskridgo for this interesting cnso. It was opernted upon nt tlıo Provident Hospital, August 80, 1900.

Tho pationt was a widower, whito, aged aixty-two years; Amoricnu, an upholsterer ly oecupation.

Tho fanily history was good, with tho oxeeption that two eousins on tho inother's aido diexl of eaneer of tho uterus, nnd two sisters of henrt disense. Fatler died of pneunonia at tho age of oighty-eoren.

Patient had leen a henyy whiskoy drinker uutil aino years ago, and ho still smokes and chows a great deal. Ho had the usunl disenses of ohildhood, but no othorg, Twelvo years ago bis lower jaw was frac. tured in a railway accident, nnd eight yenrs ago ho was cut in tho right auprnorbitnl region by nu $\mathrm{ax}$, whieh reaulted ill a paresis of tho orbicularis palpelurarum muselo. Thiere wero no congenital deformities.

The present trouble began nino yenrs ago, when tho patient noticed a tumor on the loft sitlo of tlio neck about as largo as a hazclaut, but pninless. This increased in sizo very slowly during tho first four yenre,

- Real before the othlazo Hedlcal Boclely. 3larch 18, 1901. 
at tho end of which time it was about as largo as a waluut nni painful upon pressure. During tho last five yenrs tho tumor lias grown somo. what more rapidly nid has becomo moro jaln ful, mul tho pinin lias been constant during the last year.

Tho tumor is situated on tho left sido of tho neek immeliately behind tho sternoclcldomast old musclo and partly covored by lt. (Seo Fig. 1.) It beglns theo-fourths of an inch abovo tho elaviclo mid extenils upward two nnd ono.linit Inelies. It ls two nud ong.linalf inclios long in tho loug diamotor, which is parallel with tho long $n x$ is of tho body; its lnner margin lics ono Inch from the left berder of tho trachea. The skin covering the tu mor is nermnl and freely mevable. 'Thero aro no largo vessols 10 be seen. Tho lumor feels harl, nul is so

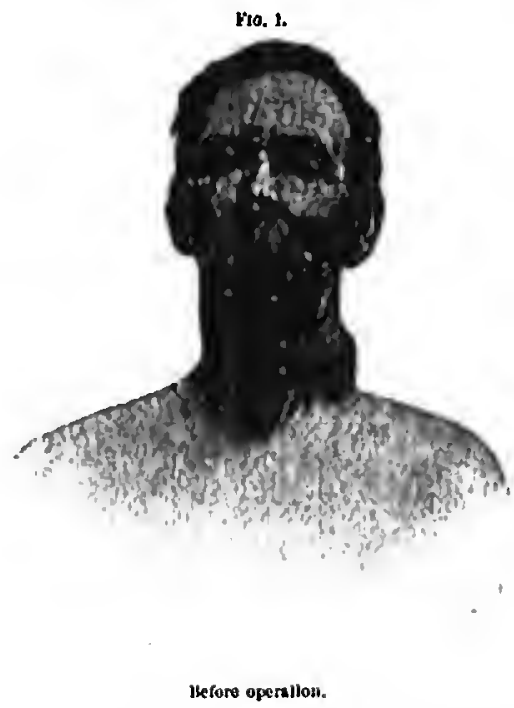

firmly nttached deep down thnt it cannot bo movel, No fuetuntion, pulsntiou, or bruit. No oniarged glands. Asplration shows, maeroscopically, briglit red blood in conshifcrablo qunntity ; mleroseopically, nothing but blool-corpuscles, neithor oplthelial nor other colls bcing found. No pressure symploms.

The physicnl oxamination of the patlent resulted as follows:

Ilody well nourished; wolght, 100 pounds; no recent loss in welght; no nburmality of skln or glandular system. Pulso, lemporalıro, aul respiration normal; appetilo good; wnlly of urtories eolt; no symptoms of pressure on sympatlietio nerves. Paresis of orbieularis palpehrurum due to old injury. Feart and lungs normal. Bpeclul ation. tion was paid to the lungs and the posilion of the dlaphragm. INver, 
spleen, eto., normal. Urino and blood count normal. Pationt was preparcel for operation by usual nethod.

An incision was mado from tho prosterior edgo of sternocleldomastoid muscle one luch beloip the mastoid proccss to the claviele. The oxternal jugular vein wns ligated and divided between tho ligatures. Continuing tho dissection, tho sternocleidonnstoid murelo was liberated nnd tho spinnl necessory nerve found and dissected out to tho trapezius musclo.

Tho tumor camo into viow nud showed a capsule which was not nillerent to any great oxtent to the eurrouniling tiesues, but was firmly

To. 2.*

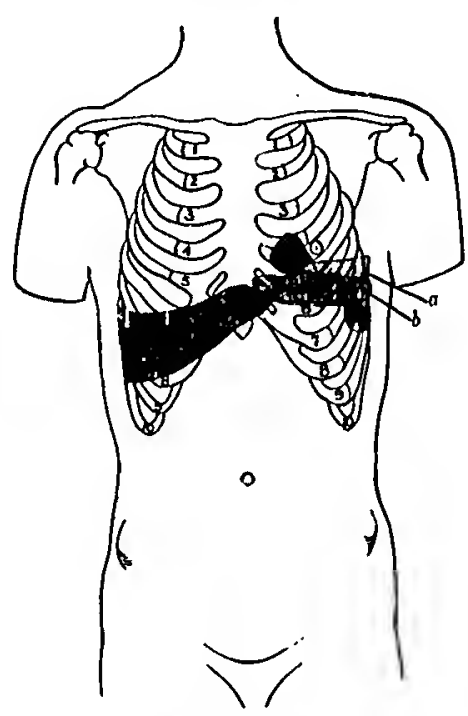

Anterlor vlew. a. Retaltre dulness. b. Abeolute duinesa

nttnclied deep down. It was an onco noticed that the plirenio nervo lay ovor the upper outer purt of it nnd that its lower bmnch wha but slightly visiblo. Thio neryo was quite teuso, but responded twlce whien it was pinelied. $\Lambda_{s}$ I belioved the tumor to bo of a malignnat nature, I did not wlsh to dlvido it for fear of Implanting cells in tho wound. Therofore, I tried to dizgeet the nerve from the tumor, but iu doing go tho sunall brauch from tho fifth cervical ruptured, and soon after the mnin branch from the fourth cervical din likewisc.

- Yige. 2, 8, and 4 : Fhidingt upon percuxsion anet diviston of nerre. n. Nelative dulnek, b. Absolute dulnew. 
I noticed no unterial chango in the pationt oxcopting an luereneo lis tho numbor of respirntlong to thirty-two. The tumor whs so situnted that tho upper and niain. root of tho plirenlo traversed the upper ontor part of it, whilo tho lower root camo from undernenth. It was firmly nitnched to the fornmen formed by tho third anl foirth cervical vertebro, and its removnl caused a venous hemorrhago from this point. The fat nud parions glands were removed frem the side of the neck. I followel tho plinenio down to tho elaviole, injuring tho thymid axis, which producod gomo licmerringe. No othor brnishes of tho phrenle wero found. In trying to unito, tho divided parts of tho uorvo, it was

Fia. B.

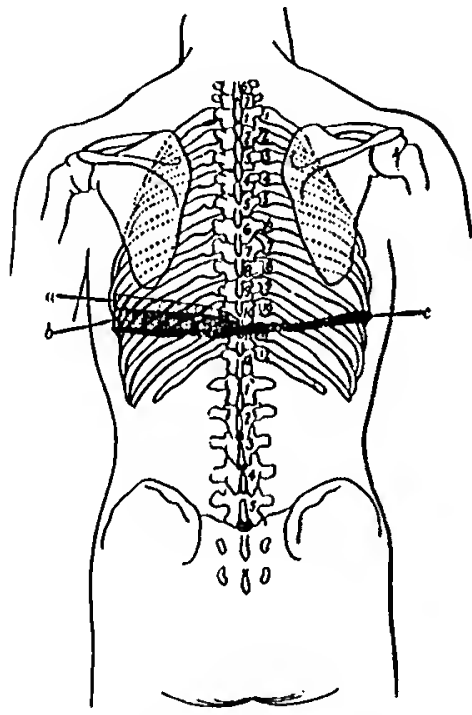

l'oxichlor vlew, o. Aelallvo dulness b. Aboluto dulner. C. Normal rido.
Fio. 1.

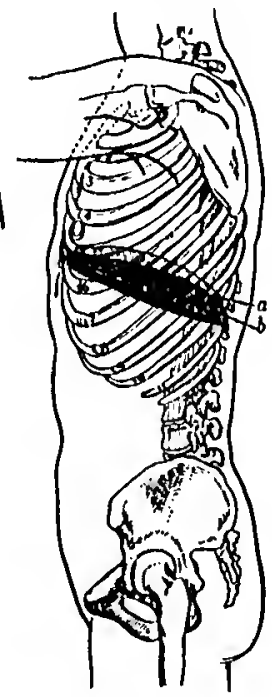

Lateral rlew. 0. Relativo;dulnea b. Abeolule dulnew.

impossible to find tho little branch frem the fifth corvical, but the raigged end of tho trunk and that of tho fourth root wore eut off in or? er to givo ininjurad cuds, and rennited by menus of silk sutures. The nerve was nor pinched below tho suturo, and respended. There was no cough, no singuleus, no sneczing, nono of tho syinptoms reported in other cases. The wound was closed in the usunl mannor. After the patient recovored conselotsncas, I nsked him whethor ho had any difliculty in brentining or auy pain in tioo region of tiso diapisrngus, but ho said ho had not. Howorer, tho raspirations romalned moro frequent (24 to 30) for four or fivo dajs, nfter whloh thoy camo down to 
20, nnd reualned so. About eight liours after tho operntion, pereussion showed that tha left half of tho diajhragn was two and onclialf Inehes abovo lts normal position. An ares of tho lower portion of tho lung, an incis and a half In wilth, showed rolative dulness. (Eeo Figs. 2, 3, and 4.) Litten's sign was nbsent.

Auseultation over dull area showed vesieulnr breatling rather distnut. Slight nbdombunl retrnetion on inspiration. Durlng his threo weoks' stny in tho hospital tho position of tho cliaphragm remained the sanic, but the nrea of relativo dulness gradunlly dieappenred and tho lung returned to its nornini condition. Messurement of the thorax showed right linlf $44 \mathrm{~cm}$. Deep expirntioll, 411 ell. Inspirntion, 443. Loft half, $43 \mathrm{em}$. Deep expiratien, $411 \mathrm{~cm}$. Inspimtion, 433 .

At present tho pntient is cniployed as usual, nnd is eufforing no ineonvenienco from his paralysis.

Aacroseopical Examination. The tminor is solid but very vasculnt. It ls two inelies in lta long dinmetor and an lneh and three:fourtiss in its trunsverse dinmeter. Upon entting tho tumor in half tho interior presentel $n$ solid consistency, but many inrgo vessels wero to be ecen. $\Lambda$ fow smail nreas, 1 cm. equare, wers somewing efter than the ninin bolly of the tilmor.

Microrcopical Exomination. Ono sces numerous connective tissuo ilbres around the porlphery, forming a well-definet capaulo, and mmiy nreas of icueocyter nround which thero scoms to bo young conncetivo tisjuo. In the contro of the tumer thero is a henorrhago lnto tho tiesio. This is vory recent, and is probably dne to the juneturo mnde by the asplrntory syringe. There nre many Inrge nind sinnli bloodvesecle, but no now ones to bo seen. Isucocytes aro grouped at varions places, resembllig an Iuflanımatory process. I beliove the tumor to bo a fibroma and not, was thought from tho clinical ovidenco, a fibro. sarconia.

\section{Experintenlal IRezearches.}

1. Upon the IIuman Subject, As beforo stated, in ail recent operations for tubercilar glands, I have searched for the phrenio nervo and pinchal it below tho lowor root, with tho followiug results: Each the the corresponding sido of tho diaphragm contrneted, produeing $n$ eudden nnt decided abdominnl rising immedintely bolow the costai nrel. This is beon dono in eightcon enses, ton right and eight left. Iu two crses, one right nud ono left, there was sonso pain in the region of the corresponding half of tho diaplingm, whleh subsidel in ench Inetnneo bofore tho ond of forty-eight hours. The symptoms commonly ascribed to irritation of tho phrenic, $i$, e., sncezing, coughing, and hic. coughing, were uot obscrvel itt a single inslance.

2. Upon Doge. Tho animai experiments hnve been niado upou dogs only, beenuse thoy resemblo nan in their type of respirntion, which is costo-abdomlual. Tho method of conduoting the experiments has been as follows: Tho cireumforenco of tho thorax was takeu at the tlp of the onsiform cartllage, nud ngnin from one to two and ono.hnif inohes nbovo it. The number of respirntions per minute were recorded 
Ixfore and after division of the nerves, and the change In type of repiration notel. Ethor was tho anmethetio choeen. Tho usual anti. septio precnutions wero olserved. Aftor oxposing tho nervo tho Interrupiel cicctrical current wns applied, and then tho nervo was piachel with an nrtory forceps. Tho nervo wiss now either ovuleed or rescetel. later in this work I weighed tho auinals before tho operntion ani each week therenfter,

l'ost-morteins wero conducted froin ono week to four monthis after the divislon of nerses. For this purposo in most esses the loge were deeply ninesthetlzed with ehloroforn, the thornx opened, the nerves fonnd and stimulatel witl tho electrienl eurrent. The varlous plienomenn wero observel, and apecinens and drawings mado. For tho detrils of tileso experinuents seo Tablo I.

It may not bo amiss to stato here that beforo obtalning tho reaults slowil In this table, thoro wero cight animals that diel, but all of these cau ho aceonnted for witliout detracting in tho sligitest way trum tho above resulis, At first I ovuied tho nerve, tcaring out froun threo to five inclies of It. Out of four cases only tro survlicel. (Beo Tallo $J_{\text {, }}$ ('uses $t$ and 2.) Post-mortens of tho two that died sijerred In ono caso of liouble ovuision a doublo jueumothernx nud in the other a pueuano. pyothorax. In tho Intter eaze, I lieard tho rueli of alr Into tho pleural cavity, and, Infection occurring, tho anlmal diecl. bivuleion of tho aervo lacerates tho pleura, aud rith an Infection is liablo to reeult in ienili fiom pueuniopyothernx; therefore, I abnindonel this method of remoring tho norvo and reeorted to resectlon outside of the pleura, removing as uuch of the Rervo as ras potsible in each saso.

$A$ thinl aninal diecl from the anksthetio beforo auy Ineigion had been innde.

live died as a result of experiments with chlorejono as an anmethetie. 'These aninuls wero given two-tenthe of a grammo per kilo, and opera. tions wero beguu two hours later. They nero not completoly under, so they wero given two-tenthe noro per kllo, and oproratlong legun after nnother hour. By thls timo they were profoundly ansesthetized, lut none of them recoverel conseioumes. They slept from two to four days, when thoy died.

lleight. The first soven wero net relghed, but uyy observations would lead mo to stato thint tho first week or two they loat in welght, nfter which thoy gained and again camo back to thicle normal condltion. In the last thee it will be eeen that they lost In welght for tho fint week, but eame back to normal or nearly so. The loss was not grent in any Instance.

Mersurements. It wiij bo seon that in the singlo division there was an increisel thoracio expansion and usually a slight abdominal retractlow, which were moro ovluent on the dlvided sklo thar on the normal sido. 
TABLE I.

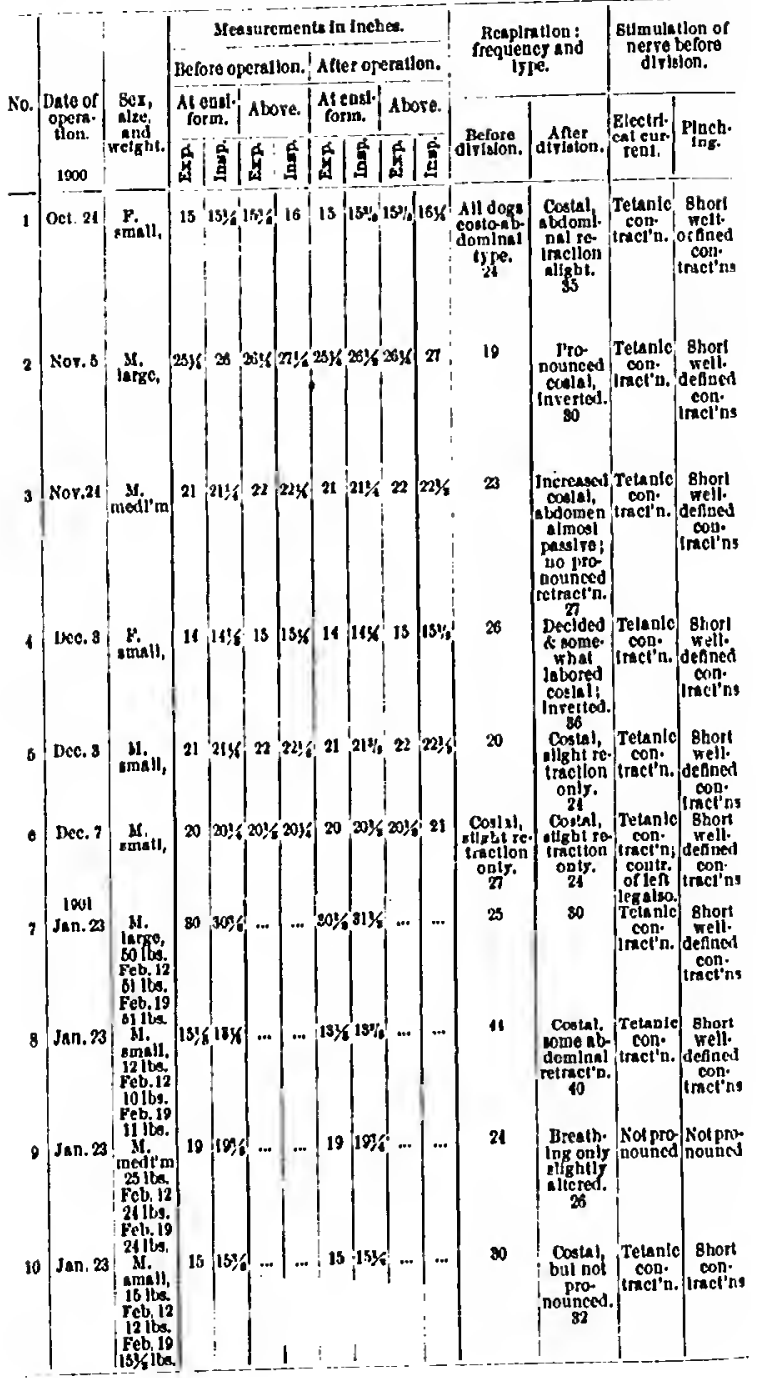


SOILOEDER, GREEN: PIIRENTO NERVE INJURIEB. 203

\section{Tande I.-Continued.}

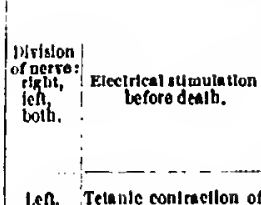

crufiton rigbl, none of len. s inches,

of Nor. 11, therlect: in in.

Xior. 11. Bone altophy of len balf of

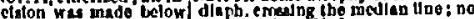
cnilform throus th ab regeneratlon of len nerre.

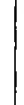

thit, Aprl 16. Chlorolorin inverted Ispo of retpln. coulsion was gtren, jlorax was tor

rghl $\$ 11$. onevied, arid lan nerre

lef $3 y^{*}$, luund ind timuleted;

doming

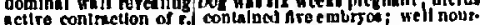
half of dingh and ras. lished.

alre of len half: ksmo-

conl ricled ilf hily.
chowlog partial regen.
crallioul; no reaclion of

MIglil, Jan. 17, I001. Dog waslsust betore litilng the

ruertlon hol and curren ap dog, mesurements

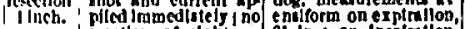

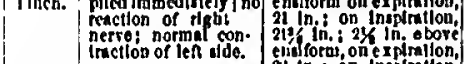

lulb. Ko reacllon.

elltorti, on expralion

2) tr.: on lastration. niturtloil

jitich.

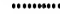

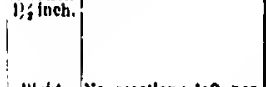

lilujt, So racilon: len nor.luleuturements beforo

resitton thal.

iifilich.

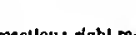

teriction action.

I!zilicti.

Itill, so rection on cliber lacillon stde.

I!: Iticb.

Ir.n. So renction of len: re-!$$
\text { (1) }
$$

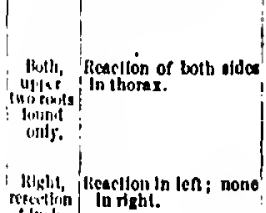

Jace 17 , Jotb nerres sow some

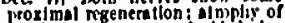

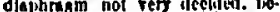
carve onty 14 dere ineed betwen the division and postanorien.

Dec. 18. Eoroe alropby of ulajhragta.

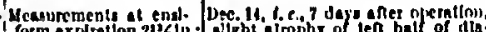
inspirnton. 84 in. ohragm enly.

Feb. 26. 100t. Very decldal atiophs of both stdes ifght slde, coulni a) a gin, ona Bndia ou aree wilich is tho atrorloto bomuse it recetres ner rrom intercosials. Fis. Costal merglu nol atrophicd.

reb, 29, 2001. Atrophy of len hatf of disphritgm: none of riglit. Hig. 7 .

Hareb 9.1001 . Y.ubenced porlion of d taphrem it enstorm cartileze is irophted, white the remalning por. clon is normal. Ftg. 8.

4ar. 9, 190t. Alrophy of right half of dinphrem, excepting one centl. malre of costal mariti. 
In tho donble divided cases thero occurred an inverted type of reaplration, $i$. e., decided nhdomiunal retractlon on insplration, and lncreased thoracio oxpansion duo to action of neceseory resplratory muscles.

Pto. $\mathbf{a}$

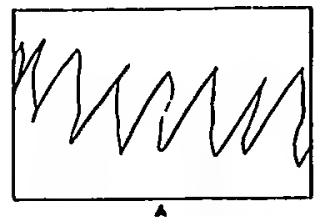

a. Excuralon of fighl half of dlaphragm.

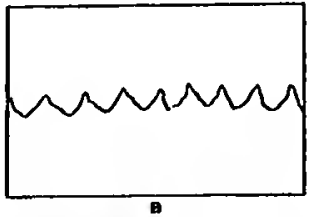

b. Peulra morement of tef or paralszed half.

F10.6.

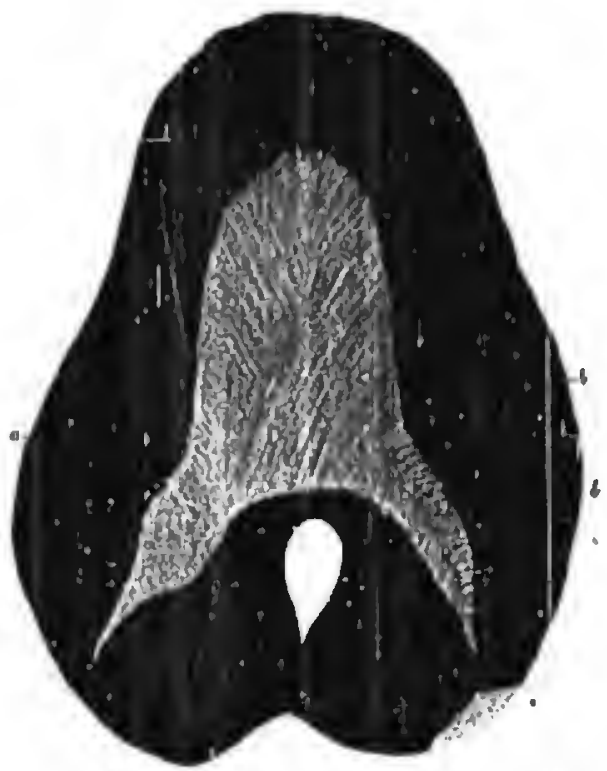

Reaction of both phrente nerves. Deg No. 7. a. Norzal area. b. Non-atrophled margin

In Case 0, ns tho uppor branches only wero divited, the animal did not suffer inuch of a chango becauso the lower branclics supply hy far tho greater part of tho liaphragm. (Seo Fig. 8.) 
SCILOEDER, OREFN: PIIRENIO NERYE INJURIEB, 205

Electrical Stimulation. In all cazes I used the ludncel eurrent ufter tho Du Bois Roymond method,' always with a positlve result, $i$. e., tetnnic controetion beforo division and no renetlon aftor tho fonrtecnth day. In Caso 6 the unimnl was killed only eoven ulays aftor divislen, and on stimulation there wos a slow, feeblo contmetion, slowing either that the ulervo was not yet entirely degenerated or that the ntroplyy of the dinphragm wos not yet conpleto. In Caso ! tho current prolueed a contrnetlon of diopliragm supplien by lowor roet. (Beo Flg. 8, b b.)

lixcursions of Diaphragm. In $\log 1$, I opencel tho abilomen in tho melinu lino inmedlntely below tho ensiform cnrtilago and lnserted n

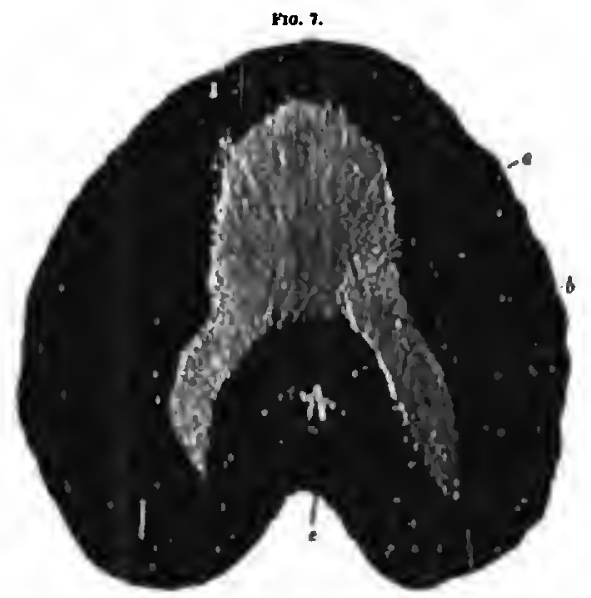

liesectlon of len phrenle nerre. Wog Ka. B. o. Non-almphled margin. b. Almphlo area. C. Heophegu.

gliss rol, purshing it agoinet first ove side of tho iliophragm and then the uther, toking $n$ kymographlo tracing (sco Fig. 6 ), with tho result that the right half centraeted nermally, preducing a riso one-halt inch in leclght on inspirntlon and corresponding depresslon on oxplro. tion. The loft hall produced a very emoll rlae, ono-olghttl Juch, representing tho influence of tho contrnetlone of tho right side. Thoro was no controctlon of the loft hinlf. In other anlmale, I observed the sane phenomena, $i$. e., that the porolyzed sido was pasave and only acted upon by tho contractioos of tho normal side.

Symploms. The dinplirogin becomes relaxed after tho division of tho uervo nnil nrchos up into tho thorax. The type of respiration beconics 
incrensed eostnl when ono norvo only is divided, nuld in vortenl when both nerves are divided. Tho nccessory respiratory auseles becomo very netive.

Thero was 110 sneezing or eoughing in any of tho minnls. In one ease of douhlo livision tho respirntion beenmo Inbored, but it reanined so for two or three dinge only.

The Post-morlem Findings. Macroscopienl. In the enses whero the log was killed froms soven to fourteen dnys nftor division tho atroply

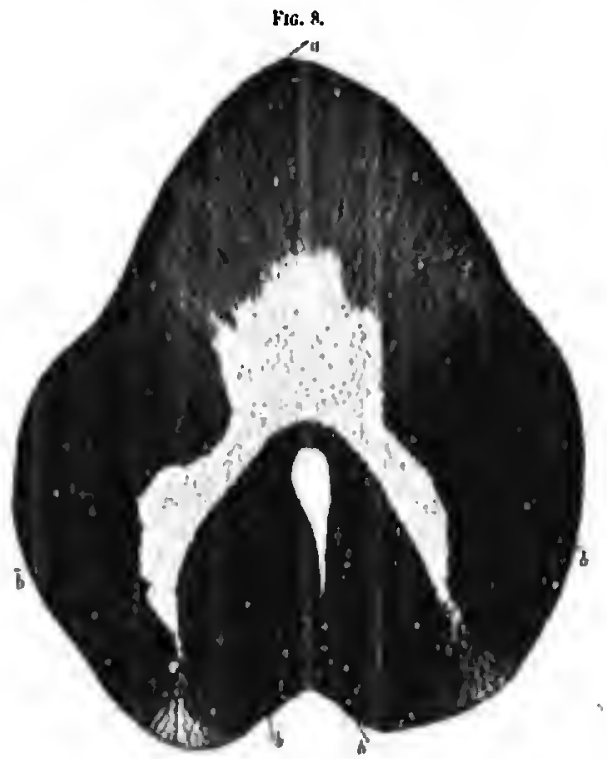

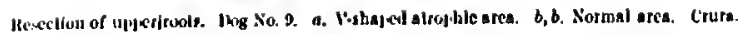

whs not very great and tho color was reddlish.yellowr. In enses where " long time had clapsed between the operation nud the post-mortcm, the utrophy was very deeided, tho paralyzel part was thlu and fabliy, tho diaphirugin was palo yellow, nad in somo of tho older cases trausklucent. In all enses there remainet a margin frow one quarter to threo.eighths of an inch wido at the costal border, which retnined its normal eolor ant thickness. Thls nargin is probably supplied from tho interenstal. (See Figs. 2, 3, and 4.) $\Lambda$ gain, in tho spceimen taken from $\log 7$ (Fig. $6, a$ ), it will loo seen that there reanius a relatively 
normal area on the riglit slde, which was probnbly supplled by a long loruah from the intereostal norve. In all threo figures there la a normat area at tho crurn. Theso areas ovidentty reeeivo an independent nervo supply.

Ia Fig. 8, where the root coming frein tho upper braneh has been ativided ( $\log$ No. 0 ), there is a V-shaped anen with its apex townard the stemum oxtending a distaneo of two and thres-guarter helies on ench sillo loward tho spiue. This is ovidontly supplied by tho upper brancties, tho tower briach supplylag nearly all of tho remaining portion of the diapliragm. In dog No. 3, although the nervo had regenerntel after fifty. four days, there was 110 oloctrienl renetion becnuse of at rophy of tho diaphragm.

'There is very lillle avallable lileraturo upon lhe experimental work oun this subject. Sir Astloy Cooper reports loaving experinented by putting a ligaturo on the phrenio nervo of a rabbit. 'I'so nulumul suffered from Inbered respirntion and died twenty minutes later. Postinertem sliewed that the nervo houl been eut.

llenocque and Eloy' reported serno oxperinents in 1883.

Ibillard and Cavalie," ln 1898, reported on the sequele of section of hoth plitrenles in tho dog.

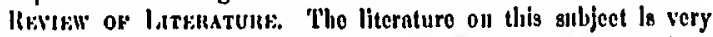
mengre and confusing, and tho conclusions renched by varlons writers are often diametricnlly opposito. 'Thus Gress' snys: "The divislen of the phrenle norve is nearly lustantaneously mortal."

liriclison," In his elghtll editim, enys: "The division of the respira. tory nerves on onse side only vouls, in all prebability, bo fatal in man by interfering with the proper perforanance of the respirntory net;" Imt ii his tentle celition" ho medifics his conclusion, nut sny's: "Divislon of lite ihrenie nervo woult necessarily, by interfering sith respiratory" lumelnents, indueo a tenilency to congestion and inllammation of the lumg; and setthough sueh an aceident must bo a very raro ono in cnecs of ligation of subelavinn for axillary nuenrism, yet it undonbtally has "recurred as I lanvo uyself wituessed ln one ense."

Rinuncy" says: "Sinco tho plumenio nervo arises in tho upper cervicsl region, any lesion of it will canso resplration to bo interfered with and

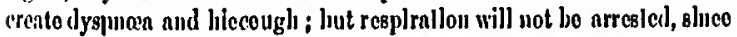
Ilie puenunognstric aorves eontimuo to excito it, and tho nuxilinry aniseles

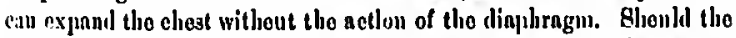
lesion be a surgleal ono, the respiratory centro of the medulla may bo affected and death take placo from agshlyy xin, but I do not think sueh a result ean bo explained ns a simplo effect of paralysig of the plirenlo nerses nleno."

Ilucter-Lossen" says: "l'arnlysis of ono-halt of the diaphrngm puts life in immediato danger. This is ovldont not only from observatlon 
of injuries to tho phrenio itself, which are rare, but from injuries to tho roots of tho verves in tho epinal cord, which determino prnetieally nlways a fatal tormiantiun. These lattor may be prorlueed by iujuries from tho fourth cervienl vertobra down, or by degenerntivo procesees epreacling from bclow upwnrd. They are alwaye indicatel by paralysis of this priucipal inusclo of respirstion, tho accessory muscles liaving hecu nlrealy moro or less porolyzed, probably completely. Dinuhragmatic paralysis is nlwoys ensy to determine, eince by it nlouc is inspirntion performel under ordiunry circumstnmees."

Jiobel" ealls attontion "to tho proporty possessed by nerves and vessels of resigting the eneroneliments of tunors, just as Langenbeek" hal much earlier pointed out in lis wcll-known Beilräge $z$. Chir. Path. der Venen. This is fortunato, since tho vogus nud plirenic nerves remaiu npjurently uncompromised by a degreo of jressuro which, a priori, it would hardly ecem as if thoy conld reaist. Thoy permit, arorcover, considernhlo displacement without interfercuce of function."

l3rollio" says: "If tho finctlon of tho cord bo interruplesl above origin of tho phrenic nerves, respirntion is immediatety suspended, and Instautaucous ileatl cusues."

l'ark" snje: "Cnses of tuilnternl tipision of tho plureaio, or of injury to tho courso of tho plironle $\rightarrow$ as, for examplo, in fractures of the cervical vorlchre-indicato that paralysis of tho dlaphragm, or at lenst of ouc-lialf of $1 \mathrm{t}$, juts tho paticat in Immeallato danger of lifo, anil alzo compels tho other acecsiory ingpirotory mucles to do on cnormons numount of eompeneatory work."

Iu a lnlor work l'ark" enge: "Tho section of the plurenio and juelumogastrio nerves on ono side only ls accompanicd by respiratory nud circulatory irregularities; thoy aro not necesarily fetal, but it is a ulogt sorious eonpliention."

Tillmam" snys: " In easo of comujleto pnralygie of tho phrenic norves ou botlı silles, dcatlı results iumedlately from paralysis of respiration, as lans heen experiusntaily domeust ratcl upou animals. Irritation of tho phrenie nervo cmues eontiuuons coughing nud hiceoughing in eonsequenco of contmetion of tho diophungm."

Lator on ho enye :18 " $A$ fter injuries of the subsenpular uervo, reflex epasm of tho phrenio nerve is sonetimes olserved with singultus, lyejuna, nud girdlo pains."

Gowers" saye: "If ono nerve onty is nffected, tho diaphragm docs not ilescend on that sido, dut tho movonients of the ottior sido lessen tho resulting defeet of movement, and it cau thon bo detected only by closo observation. Tho loss of tho nction of tho dinphraga has Ilttlc effect on tho respiratory functions whilo the paticut is at rest, but dyepuen is said to bo rendily produced by oxortion; tho breathing theil becomas quick and tho voico feeble." 
Rose" and Carless say: " Plironio nervo diviaion may causo inatant denth by paralysls of the dlapliragm, although whero but ono nervo is livided tho patlent en survivo. Irrtatlon of the nervo gives rlso to spasmodio cough or hlecough."

Medical men havo not folt noarly so alarmed at paralysis of the Iliapliragm as havo tho surgeons, possibly bccause tho leston ln medical cases comes on slowly, and In this unanner patlonts may adapt theniselves to now couditions witl les denger. Thus Bornhardt" eays: "Tho prognosis in paralygis of tho phreulo nerves nnd dlaplingm is coubteul, to say tho lenst; but, as Duehenno" has shown, the respirntlon does not suffer mueh so long as tho pationt is qulet because of tho action of the nceessory miscles, but as ono may rendily understmnd, Ironchitis and othor gimplo discases of the respirntory organs becomo seriots ln such cases."

Mony otlor statements equally divereo in conchusion may bo foumd in tho liternture.

TAIH,E: 11.

\begin{tabular}{|c|c|c|c|c|c|}
\hline cinse. & surgeon. & Yene. & Nattre of Injufy. & Nerres! & Result. \\
\hline 1 & Echltrmajer, & 1817 & stab wound. & Rigbl. & Dealb ln fer minules. \\
\hline 2 & Ecck, & I813 & Bullet wound. & Isll. & Death on offh dey. \\
\hline 3 & Mar.leteben. & 1852 & Uaknowt. & ...... & Dealb In I wo boura. \\
\hline 1 & Erlchsen, & 1891 & $\begin{array}{l}\text { Diriflon whillo liraling } \\
\text { rutelarisu asters. }\end{array}$ & ....... & Death in fer dasa. \\
\hline 3 & Mactenzlo. & 1691 & Rupturo from falt. & Jighl. & Death Imrocdlate. \\
\hline 6 & schroeder, & 1900 & Ilirlelen during opentllob. & Ien. ! & Recovery. \\
\hline
\end{tabular}

I have been nblo to find only fivo ceses of actual Injury to tho phrenic norvo (sco Tablo II.), thungh thoro nre soveral others which have been eommonly reported as sueh which, when traeed to tho original docunents, have been found to bo erroneous. In somo of theer the injury to the phrenio nervo ia only nu nesumption on tho part of somo lator writer, who, notieing that the symptoms commonly desortbel as crused by suel, an injury wero present, has inforred thant tho phrenlo nervo must certainly liavo been injured, whilo in still otlors tho surgcon has roportel an injury to the pueumogastrio, liut lans beon elted by others as haviug Injured tho phrenio.

Tho first of tho cases of aetunl injury to tho phrenio norvo ts that of Schïrmayer."

Patient was a male, aged twenty-six years, proviously woll. Ho was wounded Oetober 10, 18.7, by a knifo, whleh penetrated tho right alde of tho neek. The wound began one and one-half Inelies abovo tho acromial end of the clavicle, pasged downward, forward, nnd lnward, endiug nt the sternal end of thio clavlele. In lls courso the knlfe-blade 
iujured tho trapezins, splenins capitis, lorntor scapula, scalenl, anl

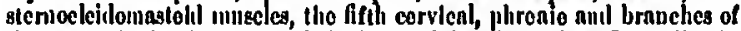
the sympatlictic ploxuses, nud tho interual jugular vein. Immedintely following tho injury tho paticnt complalned of lameness of tho right arnI, whileh liuug loosely nt hls sido. Hemerrhngo was quito severe. IIo left the roem, geing into the kitchen, ant nfter a fow comptaining werds, collapsed and died in tho couro of a fow inlnutes.

The post-mortem, which was very complete, showed mannin of vessels in skull and brain, but unusunl fulnces of vessels in lnuga. There were mumerolis nithesions of the pleura.

Sohïrunyer says that denth was net duo to hemorrhago, beeniteo of llio itegaliye post-niorten findlugs, lut that it was due to divislou of the phrcuie nerve cemplicated by these unmerous athesiens of the tung tu tho pleurn. He belioves it probable tlint enses of unilateral divialon inny recover, and rolens to Iarrey, but declares that, in tho sense of tho law, denth in thia caso was duo to hijury of the phrenic nerve.

Tho sccond enso, ruported by lleck, "wns that of a young man who whs glint li tho neck during a duel. Upon oxamination it wns tound that tho hullet hail enterel tiso fingers' brenili lis alovo this left elavielo at tho posterior border of the sternoelettennatoil, and camo out on the opprosito slilo at tho junction of the upper with tho mildllo thirl of the neck, auterinr tn tho stermocleidnuastoul unuscle. The reaplratlont was slow ninl iliflienlt, pulse wenk, pupil of tho left ojo contracterl. On the fifth dluy ho brenthel nine to seventeen times pier minuto. Iarysa. gntomy was jerformel, iluring whlich opemtlon tho pntient illel. Beek perferimed tho post-mortem nud fominl tho tollowing: Tho billet linil contused thio left plirenie nerve so that thero was an extrava. antion of hlood in tho neurileman, linil passed lonek of tho left carntid liet ween tho vagas ninl sympnthetle nerves, laeernting tho corvleal gail-

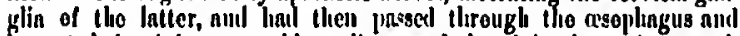
fiecrated the right arytenoid cartitage nud tho right deecendens nosi.

In conciuslen, Beck states that as the injury to the phrenic nerve resulted in a prartint toss of the function of tho ilinpliragn, it certninly couplisentel n coudition.

In geme way this ease has been attributed to Stromojer," who reperted it about 1870, at which timo ho also reported nuother caso of contusion of tho threnic und brachial plexus with ratild recevery.

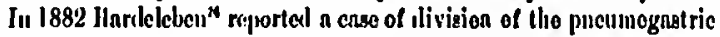
nut phrenic: nervo with uo trumedinto symptoms, bnt noon the patlent's respimtion becnino slew and difticult, and ho dical In two hours.

Itt 1884 Firiclsec1s' says: "In n en*0 with which I num acquainted,

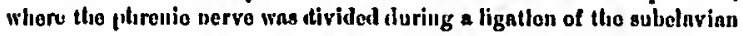
"rtery, denth resulted in a fow dnjs from cengestlon of tho luugs."

In 1891 Mlackenzie" reports a ceso af rupturo of tho right plorenio nerro with instant elenth.

It roviouring these fivo cares it will bo seen that in only ono, that is tho last one, whs there nin Iujury to the phrenio verve alonc, while iu 
all the othors thero were sufficlent Injuries to other injporlant structures to necount for the unferorable termination.

In consldering tho oflier cases, i. c., thoso coinasonly bit erroneonsly considered as phrenle nervo injurles, there nro two whileli deservo speclal imontlon, as tlioy linvo bcen so wldoly nnd frequently quoted, i. c., liransby Cooper's" and ILutiu's."

It lins been cooimonly reported thint Brnusby Cooper, In 1841, whilo ligating $n$ subelavlan artery for nneurisin, inclmlel tho plarenlo nerro in tho ligaturo. In roviowing this caso carchilly, it was found that Cooper states that the jutlent dovoleped a congh, whileh porsisted more or less violently until hila death on tho fifteenth iny. I3nt tho post-morten, which was incomplelo and was dono fiftecu hours lnter, showed tho plirenlo nervo "in situ nmi glued llown to tho acnlenus musclo." Aspirntion showed pus in tho pleurnl cnvity on tha samo side.

IIutin'a caso was opernted on in October, 1841; for wound In tho nxllln. Ilo got up on tho sixth dny, after whloli lio begnn to cough. At this tlaio tho wound wns fetid. On tho uiutlı day lie had n elight liemerrhago, and on tho tentlı day, for fear of a great licumerrliage, Ilutin ligated tho subelavian artery, but tho patlent ilied tes liours Inter.

Post-niorien showed tho artery lintnet, nnd Ilutla sjeelfenlly stntes that no norves or other inportant structures wero found in tho lighture.

Of fivo cases to whleh Pnrk"s relers as injurles of the phrenle nerve, four, three of Demmo's" and ono of Kiedel's," wore found to bo injuries of the pnounogastrle, whlle In the fittl (Ilofmokl's)" tho injury was la the eervleal plexus belew tho plirenle nervo.

leferring to the ense while camo uniler my observntion, ono inlght inler that as the tumor was of slow growth, ths gralual pressure upon tho nervo lial proslucel a slow paralysis of the tlinpliragm ; but in niswer to this, I enn say, no Iangenbeck" anil Dlabel "havo previously shown, that theso nerves withstnnd pressure without much ilisturbance; eccendly; upon pincling tho nervo four illionent times, tho epigastrio regrion on the snine sido sliowed $n$ sharp endden riso enclo tine, slowing thint thoro had been no pnrnlyeis; lastly, tho piysienl oxnm. imation beforo the operatlon showed tho dinpliragm to bo in ito sorminl josilion and tho lungs nusolutely normal.

Asatomioal. Resiarchis. Tho subject of tho innerration of tho alinpliragm wlll bo congldered under two hends.

1. Innervitlon from tho plirenio merve. 2. Immorvntion from nny other souree.

Under tho second hending will ho consldered: 1. Innervntlon trom the intercasial. 2. Innervation fren the sympatlictle. 8. Innervatlou from the pnoumognatric. 
Inneriation from the phrenio nerte. Tho phronio norvo or tho internal respiratory norvo of Bell is tho most conspieuous.nerve supplying the dlaphragm. It has, by most nuntonists, both deseriptive and com. parativo, becu cousidered tho solo uerve supply to this nusclo. This norvo will bo considered under three liends.

1. Its origin : (a) spinal or tecp; (b) cervical or superfieial. 2. Courso nnd rolntiolle. 3. Distribution.

Spinal Origin. Mnrincsco, ${ }^{2 \prime}$ in 1898 , deserilsed a uervo ceutro in tho splual cord of dogs and rablits, froni whieh proceeds tho nervo fibres of tho phrenio nervo.

ITo deseribes it ns n " group of cells which oceupy a . intermediato position botween tho nntorior intornnl and nuterior ox', rmal groups of the anterlor horu, oxtending from tho lovol of tho lower bonier of tho fourth cervienl vortebra to tho lower border of tho sixth corvical in loga, nnd $n$ littlo lower down in rabbite. In rabbits thesn cells aro not distinguisliablo from other cells. In the dog thay ane omaller and their processes less niarked."

Sane," in tho anmo year (1898), describet n motor nueleus for tho phrenio nervo in $n n n$, located in the centre of tho nnterior horn, extonding froul tho middio of the third to the sixth segment. Bensory uourens originato, ho says, in gnuglin in tho posterior roots of tho third, fourtl, fith, and sixth corvieal norves.

Superficial Origin. Most of our standnrd linglish auatonical authorlthes glvo tho origin as priucl pally from the fourth corvlcal, with accessery branehes from the third or finth, or both, but with no figures as to relative frequency of difforeut origins or the proportion in which difforont roots aro fouud.

IAlschkn, ${ }^{\text {s }}$ lu 1853, published tho results of thirty-two disecetions of tho phirenie roots, showing tho followiug results :

\begin{tabular}{|c|c|c|c|c|c|c|c|c|c|}
\hline Numb & & & & & & & & 97.5 & pere \\
\hline " & " & $"$ & fth and bih & & & 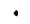 & 7 & 21.87 & $"$ \\
\hline$"$ & $"$ & 4 & Bd, Ith, and slt & & & $\cdot$ & 7 & 21.87 & $"$ \\
\hline 11 & $"$ & $"$ & sd and tib & & & 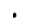 & $\mathbf{B}$ & 18.75 & $"$ \\
\hline
\end{tabular}

Brook, ${ }^{4}$ of Dublin, in 1887, reviewsel Luschka's work and reported sixtcon dissoctions as follows :

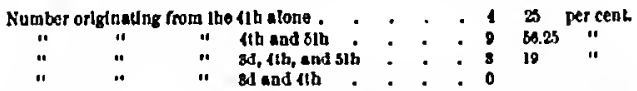

In the past four inonths, from obeervations mado in tho dissectingroom of tho Northwostorn University Medienl Bchool I hnve obtained tho following results:

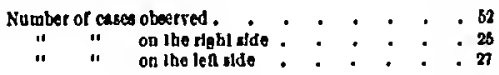


Theso nerves had the following origh :

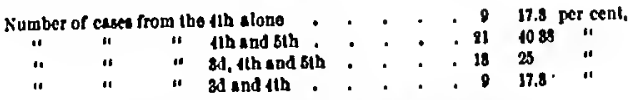

Theso various results whon tabulated ahow as follows:

\begin{tabular}{|c|c|c|c|c|c|c|c|c|c|c|c|c|c|}
\hline \multicolumn{2}{|c|}{ No, of cavet. } & \multicolumn{3}{|c|}{ th anly. } & \multicolumn{3}{|c|}{ thend $b$ h. } & \multicolumn{3}{|c|}{$8 d, t h$, and $S h$. } & \multicolumn{3}{|c|}{ Sd and th. } \\
\hline a & 32 & $\begin{array}{r}12 \\
4\end{array}$ & & "e? & 9 & $\begin{array}{l}21.87 \\
68.25 \\
10.85\end{array}$ & $\begin{array}{l}\text { ser ct. } \\
4 \\
4\end{array}$ & $\begin{array}{r}7 \\
18\end{array}$ & $\begin{array}{l}21.8 \\
19 \\
23\end{array}$ & $\begin{array}{l}\text { per cl. } \\
\text { " }\end{array}$ & & $\begin{array}{c}18.76 \mathrm{p} \\
0 \\
17.8\end{array}$ & " \\
\hline & & & & & & & & 20 & & & 16 & 151 & \\
\hline
\end{tabular}

Number of roots. When there is a singlo root it is from tho fourth cervical. This occurred In 25 cascs in 100 . When thero aro two

F1o. 9.

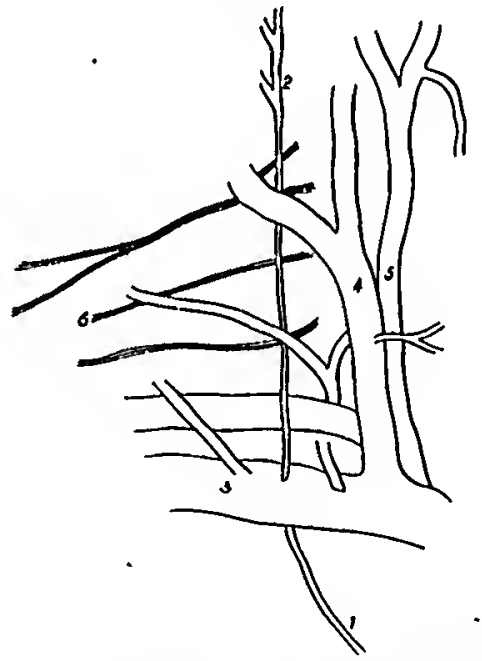

1, 2. Pbrealo nerre, subclerian rein. 4. Iateranl jugular reln. b. Common carolld artery. 6. Rooes of brachial plexus.

roots they aro from eithor tho thind and fourth or tho fourth and fifth. In 52 cases the norvo had two roots.

II 23 erses tho nervo hod thrce roots of origin, vlz, from the third, fourth and fifth.

Course. The nerve secms surprisingly constant in its courso. It is generally as deserlbed in the standard text-books, with fow varlatlons. Oino or two relations, however, are worthy of notice. 
Tb the subelavian veiu. I hnve noted this relntion in 51 cases. In 26 cries on the left gide, tho nervo passed behlnd the vein in all. In 25 enses on the right side, the nerve passel behlud tho vein in 22, in front in 2, and in tho ronmining caso passed threugh the vein. (Beo ligs. 9 and 10.) Of this pecnlinr anomaly I have been nble te find but ono similnr cnse reporter in the liternturs. In Virchos's Archiv for 1872, Ven Wenzel Gruber," of St. Petersburg, reperted a caso of the loft subolavian voin dividing and rcunitlng so as to form "an Island four millimetres long nud two millimetres wide, through which passed

F10. 10.

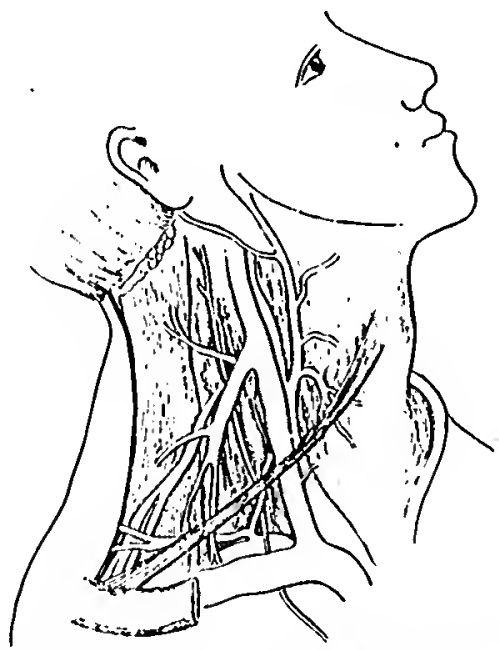

Coureo of phrenlo (righl) in neck, vboning reiallons to adjacent stroctures.

tho left phrenic nerve." IIenoeque ond Eloy, in their nrtielo on the phrenjo nervo, in the Dirtionnaire Encyclopedique des Med. Scien., any that Iouget has ulserred a similar enso, but I was not able to find any descrlplion of it in his work on the Nerrous System.

Faweett," llarten," Walsham," IIuntor," and Turner" havo reporled one case cncli of thio plirenio passing in front of tho subclavlan veln. of these five enses, three wero on tho left sile and two on tho right. It is probnbly comparatively common.

I folmul this nnomaly present twice in 51 eases, or nearly 4 per cent. It secms wortlyy of noto on accomnt of its relation to tho elaviele. When 
lying in this nnomalous position it is immedintely belind the posterior surface of the clavicle, and might be Ineerated or diviled in fracture of tho elnviele or inchuded in the callus.

Relation to the Internal Maminary Artery. At the origin of the orlecy : This relation whs obscrved 22 times on tho loft side and 20 times on the right, or 42 times li nll. In 22 eases ( 8 right; 13 left) it was externul to tho origin of the artery. In 13 cases ( 6 right ; 7 loft) it was internnl. In 7 enses (b right; 2 loft) the norvo passed directly over the origin of the nrtory.

Relation of the nerve to the course of the ortery. This relation was olizerval in 32 cases, of which 15 wero on the right side and 17 on the Icft sicle. On the right side there wero 14 cases in which the nervo was intermal to tho artery and ono in which it was oxtermal. In 17 enses on the left sillo, the nervo was intornal to tho artery in 13 enses and exterunl in 4 enses. In a total of 32 enses obsorved, then, tho nervo lay interunl li 27 nud oxternal in 5 coses.

Distribution. 'Tho main distributlon of the nervo is to the dinplirngu. Sinall twigs, varying li utumbor, aro sent to the superior voun enva, tho pleurs, and tho pericardiun. Insehkn has described branelies to tho right nurielc. 'This olservntion I linvo not been ablo to eeufirm. Tho iranches in tho thorax aro small and easily destroyed, henco woro not acmonstrablo in many enses on necount of tho parts lanving been dis. turhal before obsorvations conld to malo. The branch to tho superior veun enva from tho right plironic ls very constant, nud enu, I think, bo clemenstrated in all enses where tho integrity of the parts lias been preserved. Branclies to the pleura and pericardimm vary in ummber from I to 4 to encli structure.

'The ceurse of the main trtuk of tho nervo is as genornlly deseribed, the left phroalo boing longer and lanving a couree far to tho left over tho perienrlium. It brenks up into its termhnal brnuelses nbout 3 or $4 \mathrm{~cm}$. alsove the thorncic surfaco of the dinplurngas. It mny romnin intnet mutil it picrecs the dinplirngn nud dividle in its substance or on its lewer surfnee. In 29 cases in which the point of division ras noted, tho nervo divided abovo the dinpliragm in 18 , and in the substance of the innsclo in 11 cases.

'The statencnt made ln somo of our standard linglish works on anatomy, that the right plironio passes through the opening for tho inferior vena enva, ls not borne out by tho observatlons unalo. In tho great majority of eases the worve passed through a separnto opening a few ecntinetres in front and to tho right of the opcuing for tho vein.

Tho dinphrngmntio branches aro from 2 to 6 iu nunber, nad nre distributel to the latornl nud antorior portions of tho muselo, divilling and suldividing into fino norvo filnmente, and soon losing thomsolves in tho substance of tho musele. Tho oxnet nrens supplied aro as yet undeter-

YOL I2Z, NO. 2,-TERRUAY, $1902 . \quad 15$ 
mluel. The single ense of a dog observel by Dr. Beliroeder, in whichi section was maile of the upper rools of origin of the phrenio, the lower heing unimpairal, ts the ouly case of the kind I know of. In thls dog post-niortem showel degenorntlon of the anterior and milldle portions of the muscio, with tho interni portion normul. I hope nt some future time to mnke some further oliservntions on the exnet cilistrilution of theso torminal brnuches.

In 15 eases the right pirenio perforntel, in 12 caecs branehes were observed beiow the ilinpiliragm, nutl in 8 cases it was possibio to trace lirancices to the eninr pioxus. Troo very careful discetions on unueually favoratslo enses sloowel lirniches of distribution as descriliet, vlz., to the eoullunar gnuglion, to tho suprnienal ant hepatic ploxuzes. 'Theso brnueics of communication lin overy enso observet cane from the innermost terminal bmueh of the right nervo, which piereer the dinplimgiu olese to the inforior venn cavn anul rnn downward and inservl, retroperitonenlly, to the semilunar gnnglion. Whether the

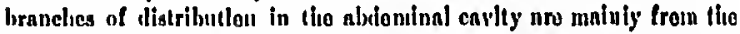
plironle or the sympathetic, or whether the brnneh connecting the rigit phrenle with the solnr ploxiss is an nfferent or an efferent braneh, is as yet unidetermined. In uo ease vere nlyloninal brancices observed on the lett side.

Thio question of decusantion of uervo flires is unileternined, and upou this wo lanvo conIlieting ovidenee. Kohnstamın," in his Studiell n̈ber deu Phreniciskern, says: "Inucrvation of diaplimgmuntio halves is distinetiy biinternl, iunsumeh as ench plirenio supplies only the sane sille of the dinplirngn nud comes only from nueleus of anme silic, whieh in the rabihit lies from 6 to 10.4 segneents of cord. $A$ erossing of periphl. oral nerves lut the anterior eemmlsanre does not oceiur in the pirenic. Ventral part of dinplirngou is aupplied by n crnuini trunk nutl loreni hy n coudal trunt."

On the other hand, Ilonosque nul Eloy" eay: "The peripheral liranches of the nerso (pirenle) forn a plexus which completes tlie nnnstomosis lict ween the two needinn linlves of the ilinphrag in."

Tho queation of nervo communleatlon between tho two medinn haives of the musele is unost important, but as yet undetormined.

Inservation froun the Intercostal Nerves. Iatechkn," in 1853, pulllishel a monograph on the phrenie nervo, in whleh he says: "Tho lloshy portlon of tho diaphragn recoives motor filnnents froun tho Intercostals froun the sovouth to the trelfih." Inter ont, in hls Acutomie des . Meuecheo," he says, lit doseribing the last two Intercostal nerves: " Daring their courso along the last slx rils theze nerves supply not only tho Intereostal museles, but also, se I havo previously dieseriberl, the cestal portlou of the dlaphringn. These penet rate into the coetni illgitntions of the dinphrngu in company with the terminal branches of 
the arteries, and nro nanally so fine ns to consiat of prinitive norvofibres."

Provions to Lusehkn, howover, Baner," Meekel," nud Valentino hnd described branches to the diaphragm in man, comlug from tho lowor intereostal nerves. Their exnct or gin and distribution lind not, however, lieen determined. Their work, howover, serms to have been genornlly overluokel, or, at lenst, not enphaslzed. Cavalio," writing In 1886, enys: "Thoy aro not meutioned in muy of our stnulard nuthors, exeept a foot-noto In Benuner and Bouchard's Anatomie."

Among lingliah nuthorities nlso these branches secm to havo beon overlooked. Qunin," In lis last edition, refors in n foot-noto to lanschka's work In a general way. McClellan" simply enyz that anch liranehes exist. Gerrish and Morris mako no mention of them. Gray" dnes not refer to then provious to tho thirtcenth editlon, into which is interpolated the statonent that filanents from tho interestals havo heen traced to tho dinphragm. In most comparativo anntenics there is $n 0$ reference to this nervo supply. Chanvenu, ${ }^{\text {, }}$ Mivarl," Welder. pleim," Wilder and Gnge," nad Ifuxloy" make no mentlon of lt.

In t888, l'ansinl, ${ }^{,}$of Naples, described a subdlaphiragmntie ploxus in rahlits formel by " tho phrenlo and also braneiles tren the three intereastnls." T'his ploxus he subillylles Into threo: anterior, nild lle, and posterior plexues. Ifo also describes numerens ganglin in these piexuses, cespecinlly in the posterior one.

In 1890, Cavalic, ${ }^{\text {s }}$ of Toulouse, published the results of tho diescelien of six adult human diaphrngnes, or 12 Intoral halves. lly dividling tho diaphirngm in tho medinn line and sawing through tho eplunl vertebrn lougitulinally he removed eneh hinlf of tho dinphrngm intnet, with its costal nunl sertobral attachneuts. After nuneernting tho part in a wenk solution of ultrio neid, ho demonstrated diaphirngnintio branehes fron the intercostal nerves, with the following origins:

1. There aro no dinphrngmatlo bramches fren the sixth intereostni nerve.

2. 13rmuches wero observed coming from tho eloventh, oighth, nad sereutio most ahusednatly, then from tho tenth, twelfth, nud ninth in the order named, the list being reintively peor in brnaches.

Churse. Diaplirngmatio branches ariso from tho Intereostals juat as the latter pass over the Insortion (costnl) of the dlaphingm. Thoy either pierce the aponcurosis (of the internal intercostal musclo) or pass through its interstlecs, and nre directed toward tho muscular fabres of the diaphragin. Thoy aro sometimes nlone nnd somotimes necompanled hy tho brniehes of tho Intoreostal ressols. Thoy number if or 6 fron each intereostal nervo.

Distribution. Theso dinphmgntatic branches frem the intorcostals 8upply a narrow margin along the costal bordor of tho diaphragm, 
varylug from 1 to $3 \mathrm{~cm}$. in wtlth. Cavnlie was not ablo to recognizo any nnastomosis of these fibres with tho term/nal branclies of tho phroule, nor did ho observo any of tho ganglia describal lys Pansinl.

In Inter papers, pteblisicel in 1808, Cavalic amil Iliilard ${ }^{\text {st }}$ report the results of two sorice of exportments. Bhy the first "they demonstrotert the oxistonce of motor fibros In the dinphragmatic branches of the intercestnls. In tho eccoul serles" they proved, by plysiologleal oxperimentation, that tho intercestal norves eannot asenme tho rolo of tho plitronio aftor livision of the phrenie itsclf.

Silmulation of tho peripheral ends of the ctividet intercostats in tho fist sorles of experlnonts sliowed visiblo contractions of an nen of about $3 \mathrm{~cm}$. wide III tloga, null of n length about equinl extending in the directiou of tho muscular filires. Traclugz of these contractions wero feablo nut of sllght amplituila. In tho second sorles of oxperliments tho Investigntors euclenvorcl to nsecrialn If the intercostal nerres could asaume the risle of tho plirenie In innervnting tho tliaphrngm after sertion of tho latter nerve. They decldel that it could net, although Jiapluragunatio contractlons on atiuunlatiog the lutercostals wero greniev iu $n$ dog whiese plirenle liad been ent $n$ mouth provious than in one where the pilinenio had loeen distled just provinus to the oxperiment. Instend of ludienting any viearlous netion of tho Intercostals, however, Or. Selirorder is of tho opiulon, from his oxteuled work ou logg, thent this is diue to a sinule liypertreplyy of tho muscle fibres of tho costal neargin of tho iliaplingm following parnlyals of nll tho reat of the uuselo, aut not in nny way nn nssumption of tho function of ono nervo hy another. This eortuiuly appienrs moro rensounble.

Caralie's couclusion tron his physiolngicel oxperimentatlan, then, is that tho diaplimamiatio lirancles of tho intercostal nerves cennot, in nanumals, nevimuo the rolo of tho phrenio after illvision of tho latter.

IJatcr, lin 1898, Cavalige publishecl the results of an extendecl acries of olservontions on mnmunale nnd birls, with four nelditional humm dis. sections, confirming his provious obsorvatlons, aml liringing hie eorics of dissections us to twenty tateral halves. His obsorvotions on mammals wero nialo ou Ings, rabljits, gulnen-pigs, nnil rate, on blrde, on tho enck, jlyenu, apnrrowlinwk, and Juek. Ilis obsorvntions on cloga nro nost interasting, nnd his leseription of tho varieus branches of innervatian of tho dlaphrngm vory minute anul nccurate, but we can only give liis fiual couclusions :

I. Tho iutercostal norves senul branches to tho ilinphragin In blels aild manmans.

2. In birla nnil manumals theso branches contaln motor fibres. They probably do in man.

3. Thoy play $n$ cortaln rolo in respltration, secondary in injportanco alter tho nppearauco of tho phrenie. 
1- 4. Birds have no phrenio nerve. The diaphragm la principally aupplied by the thoracle ncrves which correspond to the intorcestals ln manmals.

5 . As ono leaves birds nut approaches mammals tho rolo of the phrenic becomes woro important, and the area gupplled by it becomes grenter; whilo tho rolo of tho intorcoslals becomes less important, aud the area supplied by them becomes smaller.

(i. In rabbits, guinen-pigs, and rnts tho lnat fivo intereostals ecul iramelies to tho cllaphrogmo. In clogs tho last soven, especlally tho cighth, nintl, tentl, and ele veutlr.

7. In man tho last gix, eapecially tho soventh, clghelh, and cloventh.

8. In dogs tho arca supplied is tho cosla] margin of tho dinphrngm for a width of abnut $3 \mathrm{em}$. In a man for $n$ varying wldlh of $1 \mathrm{tn} 2 \mathrm{~cm}$.

1 havo roviowed Cavalio's work at length, as ho has dono lho largest amount of work nlong thls lino and, 80 far as I know, his investigatlon日 have nover been roviowed In Finglish.

Sympalhetio Nerve Supply. Tho lumormost branch from tho right phrenio com munleates with tho semilunar gangllou of tho solar ploxus. 1 was ablo to deinonstrnto thls conmunleation but sino tlmes, but found it in all cases whoro caroful dissectlons woro mado on undislurbed struelures. Whethor theso nerves aro afferent or efforout is etlll umletoruined. In no ease did I observo any abdomlual bramelies from lho left phrenlo.

Sunsark. Our conclusions muy bo summed up as follows :

1. From tho clinleal and oxporimental dats it would scem that thio diuplinaga is not au essential nuleclo of resjiratlon.

2. Than as thic symptoms conmonly described as caused by an Irrltation on tho phrenlo wero uniformly nbsent not only in tho operation, but in all of tho experimental work as well, it ls ento to lufer that Iliey mny lan'e been diso to sometling otlice than a simplo lnjury to llio plisenic.

3. That whllo from nu unntomical polnt of vlow tho diajhrngm undoubledly is cuervated by brauches from llo intercosial nerves, thls uerve supply is sccondary to tho phrenic and is Ineuficient to enrry on tho action of the dinphragm aftor a division of the phirenlo.

4. That n division of tho phrenio nervo, produciog n partial collapso of the lewer lobe of tho lung on tho affected sido anil an ntrophy of ouc. balf of tho dlaphragm, might predisposo to infeclion of tho lung or be tollowed by a diaphrogmatlo hernin.

5. That n dlvision of omo phreulo nervo in man, resuling lo paralysls of onc-lialf of the diaphragm only, is not necossarily fatal.

BIabIooRaply.

1. Nurphy, 3. n. Surgery of the Lung, Journ, Amer. Mled. Awoc, rol. $1 x \times 1$. p. 333.

2. Fenger, C. Thoraclo Duct Infurtes, br Plummer and schrooder, Annalis of Burgery, vol. xxrill, in 229.

3. 11:ll' Pbydology, p. 69.

4. ('coper, 81r Asller. Guy's Llospleal Re nort, rol, J. tQ. L., 1770), 2830. 
5. Llenociuo aud Eloy. Absiract In Compt. Rendu, 1882, Parls, 1883, rol, xl. p. 802.

6. Dillard alld Cavalle. Sur quelques effeth consecullets a Ia rescetlon des deux nerfes phrealques ehea lo chlen. Comjtes Rendu, 1828, p. \$29.

7. Orows. 8ysten of 8urgery, 1972, bth td., rol. Jl. p. 423.

8. Fircheti. Byatem of Surgery, 8th ed, rol. t. p. 285.

9. Rrlehten. Jbld., loth ed., tol. 11. p. 208.

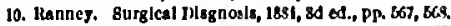

11. lluetcr-Jossen. Chlmigle, vol. IJ., elled by lioswelJ thart, Thas. Amer. Surg. Ansoc., JQ9r, vol. IIll. p. 268 .

12. Dlabel. Thesla uber dle Traumatlecho Vages Puraljes, Misnchen, 1881. Chted hy Park.

13. Jangenleet. Belirigo z. Chlr. I'ath, der Venen (Areh. f. t.!n. Cblx., Yol. I p. 6?).

If. Bmdle. Sledlco-chlrurglcal Treneselloon, rol. x x. p. I55.

16. Park, $k$. Transactlons Amerlean Bundeal Aseoclation, 1833 , rol. xlll, p. 253.

16. 1'art, R. Treatleo on Burgery, condenead elltion, 1899, p. 800 .

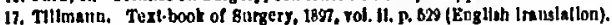

18. Tyllmenn, Ibld. rol. Ill, 11, 632 .

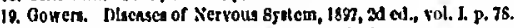

20. Rose and Carless, Jenual of Burgery, 81 cd, p. 814 .

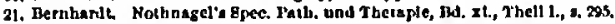

2. Duchentie, J. 1 bid.

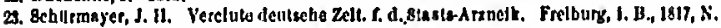
F. 1., 291-229.

21. Bect, Monogra ph dlo \&ehuse vunden Wahrend den Jabren, 1848-19, p. 154, Fall 7.

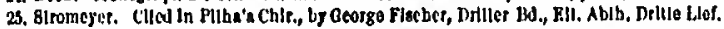
ง. 25 25.

20. Hariolelan, cried by Konlg and Hiedel, Deul. Chif., Lief. 80, I882, s. Ita

97. Mestenalo. Med, Lez. Experl cuces In Calcutha. Eilinburgh, 1891, p. 9.

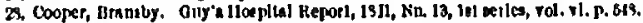

29. Ilutla. Anu. de la Chle, Pranc. el Elrangeje, Parlo, 1812, vol. Iv. Pp. S, 11.

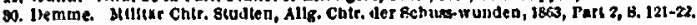

sl. kledel, Hepl. kitn, Hoch., 188, 8.513.

92. llufook1. Wiener berlctit des k. k. krankea ansialt.

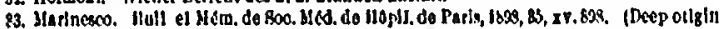
of phrenic.)

31. Bano. Journ, Jled. de Arusecls, 1828, No, 42.

85. J,uschka, Jer Nerrea Jhrenleus des Henchen. Tublugen, J853, p. 12. (A bsincl in Arch. do sol., Iratlo, 1851, vol. Ir. 1. 281.)

85. Brook. Tramacllons Arademy of stedlclne, Ireland, J857, rol, T. p. 851.

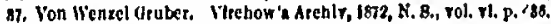

33. Feweelt. Jouroal Anatoray and 1'hye, Joodon, J85j-91. rol. xxvlil. p. 161.

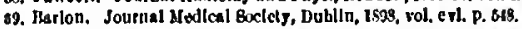

40. Waleham. Et. Itartholower's Ifospllal Jeport, London, 18\$, rol. Irl. p. 100.

11. Jlunter. Phl ladelphls sedlenl Tlmes, 1873, rol. Jy. p. 630.

12. Turoer. Jourual of Anatomy and J'hrsfology, vol. vi. p. 102.

13. Kolinstamb. Jerlin. kllnlech. Wochenschsin, 1829, No. 85, p. 697. Fortachrin u. Jied. Berlln, J838, vol. xrl. pp. 613, ass.

11 1.usebtr. Anatomile dea slensehen, 1802 , vol. I.

15. Jisuer. Traetatus de nervis siperficlalls anterloria lruncl but anla, elc, Tubingen, 18I8.

16. Jechel. Msuuel d'Acalomlo generalo, 1825.

17. Qualil. Anstomy, gtl elltion, 1832, vol. 1. pp. sto, e0t.

18. Jicctelian. Jeglonal Anatotoy, rol. t. pp, J3, 177, 201 .

19. Grsy. Auatoms, 13th edlllon, Pp. 633, 8t3.

50. Chaurea's. Comp. Auatomy of Domeatteated Anlmals, p. 85.

51. MllratJ. The Cat, p. 278

62. Weldernlielu, Coir p. Anntomy, p. 12 .

43. Wilder and Gage. Analomlcal Teclinology, p. $8 \times 3$.

6i. lluzley. Comp. Analony of Vertcbrate Animals.

55. Panslni. Arch. Jialleno de Blolog., J8s3, val. xvJ. p. 259.

56. Caralle. Inmervatlon du dlaphregm jar len Nerfs Inlercostaux, Jouru, de l'Analomie, Parts, 18\%, yol. xxxll, p 199.

57. Blllard and caralle. Compt. rend. 8oc. do Blolog. de Paele, 1898, p. so6.

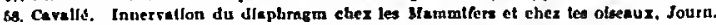
Anal., Parls, 1800, Tol xIxlt, p. 6.12.

59. Bjlard and Curalle. Corop1. reod. Soc. de Blolog., Papis, J898, p. 329. 